\title{
EVALUASI KUALITAS SOFTWARE "SIPUSTAKOM" DI PERPUSTAKAAN STMIK AKAKOM YOGYAKARTA
}

\author{
Sri.Wahyuni \\ Perpustakaan STMIK AKAKOM Yogyakarta \\ џuniavub@gmail.com
}

Otomasi perpustakaan merupakan kebutuhan perpustakaan yang tidak bisa ditawar lagi. SIPUSTAKOM merupakan salah satu software otomasi perpustakaan yang dirancang dan dibuat sendiri serta dimanfaatkan oleh perpustakaan STMIK AKAKOM. Software yang diaplikasikan tersebut perlu dievaluasi untuk mengetahui apakah mampu memenuhi kebutuhan otomași perpustakaan. Penelitian ini bertujuan untuk mengetahuigambaran dari program aplikasi yang dijalankan dan untuk mengetahui kebutuhan otomasi perpustakaan STMIK AKAKOM serta untuk mengevaluasi software berdasarkan perspektif kebutuhan otomasi perpustakaan. Teknikpengumpulan data yang digunakan adalah dengan observasi, inteniew dan dokumentasi. Penelitian ini merupakan penelitian deskriptif kualitatif dengan pendekatan studi evaluasi. Berdasarkan hasil analisis data diketahui bahwa dari dua puluh sembilan item dalam pemenuhan kebutuhan otomasi perpustakaan STMIK AKAKOM Yogyakarta, ternyata terdapat tujuh belas item yang sudah mampu terpenuhi dan masih terdapat dua belas item yang belum mampu terpenuhi oleh software aplikasi SIPUSTAKOM. Dengan hasil tersebut hendaknya ada penambahan fasilitas yang lebih lengkap agar semua kebutuhan otomasi perpustakaan dapat terpenuhi. Penambahan fasilitas tersebut meliputi penyediaan menu pengadaan bahan pustaka, menu penelusuran status buku yang diproses, penelusuran berdasarkan subyek, menu input data anggota, menu pemesanan peminjaman buku, pembuatan laporan koleksi berdasarkan pengarang, pembuatan laporan buku yang hilang, menampilkan laporan jumlah pengunjung dan menu laporan atau informasi jumlah. anggota.

Kata kunci: Evaluasi, Software, SIPUSTAKOM, Otomasi Perpustakaan

\section{Pendahuluan}

Komputer merupakan fasilitas yang digunakan dalam mengaplikasikan Teknologi Informasi. Kehadiran komputer di perpustakaan sangat memberikan manfaat dan kemudahan bagi kelancaran kegiatan dan manajemen perpustakaan. Dilihat dari segi kemanfaatannya komputer mampu mengolah data input menjadi data output, menyimpan data yang jumlahnya relatif besar, dan mampu memanggil kembali data yang disimpan dalam waktu yang sangat singkat sesuai dengan program yang digunakan. Lebih lanjut dijelaskan oleh Direktorat Jendral Pendidikan Tinggi (2004).bahwa ada.beberapa pertimbangan yang diajukan mengapa perpustakaan harus memanfaatkan komputer yaitu antara lain adalah untuk meningkatkan jumlah dan mutu layanan perpustakaaan, tuntutan untuk menggunakan koleksi secara bersama, kebutuhan untuk lebih mengefektifkan tenaga, kebutuhan akan efisiensi waktu, keberagaman informasi yang dikelola dan kebutuhan akan kecepatan layanan.

Dengan semakin beranekaragamnya berbagai koleksi perpustakaan, data anggota, transaksi sirkulasi bahan pustaka, pengolahan bahan pustaka serta berbagai data statistik, saat ini muncul kebutuhan akan penggunaan Teknologi Informasi untuk otomatisasi di perpustakaan. Untuk mengefisiensikan dan memudahkan 
kegiatan pengelolaan - sperpustakaan serta memudahkan pemustaka dalam penelusuran informasi, maka perpustakaan STMIKAKAKOM Yogyakartamemanfaatkan sebuah software otomasi perpustakaan. Software yang digunakan oleh perpustakaan STM!K AKAKOM tersebut adalah program aplikasi yang diberi label dengan nama "SIPUSTAKOM".

Selama software aplikasi SIPUSTAKOM dijalankan belum pernah dievaluasi oleh pihak manapun yang berkompeten dengan manajemen perpustakaan terutama evaluasi mengenai software yang dilihat dari sudut pandang perpustakaan yang terkait dengan kebutuhan otomasi. Dengan kondisi seperti itu kemampuan dari program aplikasi tersebut belum diketahui apakah sudah layak dan sudah memenuhi kebutuhan otomasi untuk kegiatan perpustakaan STMIK AKAKOM Yogyakarta.

\section{Rumusan Masalah}

Berdasarkan uraian tersebut diatas, maka penelitian ini dilakukan untuk mengevaluasi software aplikasi SIPUSTAKOM yang dimanfaatkan oleh perpustakaan STMIK AKAKOM apakah sudah memenuhi kebutuhan utama otomasi perpustakaan. Jadi penelitian ini hanya dibatasi pada evaluasi software "SIPUSTAKOM" dilihat dari kebutuhan otomasi yang berkaitan dengan modul utama otomasi perpustakaan.

\section{Tujuan Penelitian}

Penelitian ini bertujuan untuk mengetahui kebutuhan otomasi perpustakaan STMIK AKAKOM dan untuk mengevaluasi software aplikasi SIPUSTAKOM berdasarkan perspektif kebutuhan otomasi perpustakaan.

\section{Landasan Teori}

\section{Software}

Software atau perangkat lunak adalah serangkaian program, prosedur dan dokumentasi yang berhubungan dengan pengolahan data (Setiawan, 2005). Sedangkan definisi : software diartikan sebagai deretan instruksi yang digunakan untuk mengendalikan komputer sehingga komputer dapat melakukan tindakan sesuai yang dikehendaki pembuatnya (Kadir dan Triwahyuni, 2005). Dari kedua pendapat tersebut dapat disimpulkan bahwa software merupakan serangkaian program, instruksi yang berkaitan dengan pengolahan data yang digunakan. untuk mengendalikan komputer sesuai dengan perintah.

\section{Evaluasi Software Aplikasi}

Dalam Kamus komputer (1996) pengertian evaluasi adalah penentuan suatu nilai oleh sebuah program yang dinyatakan oleh sebuah rumus atau langkah yang ditetapkan oleh instruksi program. Dari definisi diatas secara garis besar dapat disimpulkan bahwa pengertian evaluasi adalah penentuan suatu nilai. Ketika seseorang memberi nilai sangat baik terhàdap sebuah perangkat lunak, orang lain belum tentu mengatakan hal yang sama.

Evaluasi software aplikasi adalah menentukan suatu nilai dari suatu software aplikasi. Dalam penelitian ini akan mengevaluasi atau menentukan nilai perangkat lunak (software) aplikasi SIPUSTAKOM berdasarkan sudut pandang kebutuhan otomasi perpustakaan. Jadi dalam konteks ini evaluasi software SIPUSTAKOM dinilai dari sejauh mana software tersebut mampu memenuhi kebutuhan utama otomasi perpustakaan. 


\section{Cakupan Kebutuhan Otomasi}

Kegiatan yang terkait dengan kebutuhan otomasi perpustakaan adalah (Hakim, 2008):

\section{a. Pengolahan}

Kegiatan pengolahan yang terkait dengan kebutuhan otomasi perpustakaan adalah klasifikasi, pembuatan barcode, pelabelan dan katalogisasi (input data dalam database perpustakaan).

b. Pelayanan

Kegiatan pelayanan yang terkait dengan kebutuhan otomasi adalah sirkulasi, penelusuran informasi, pemesanan buku perpustakaan dan keanggotaan.

c. Administrasi

Kegiatan ini meliputi surat menyurat misalnya surat penagihan peminjaman bahan pustaka dan pembuatan berbagai laporan yang dibutuhkan perpustakaan (laporan statistik).

\section{d. Pengadaan}

Tugas otomasi yang berkaitan dengan pengadaan meliputi pengumpulan informasi dalam rangka memperoleh masukan untukkegiatan perpustakaan."

Fitur-fitur yang mengakomodasi kebutuhan otomasi perpustakaan dimulai dari pengadaan, pengolahan, penelusuran, manajemen anggota dan sirkulasi (Supriyanto dan Muhsin, 2008). Pendapat tersebut secara tidak langsung memberikan arti bahwa fitur-fitur tersebut dapat dikatakan sebagai cakupan kebutuhan otomasi perpustakaan. Dari beberapa pendapat (teori) mengenai unsur atau elemen utama cakupan kebutuhan otomasi perpustakaan pada. prinsipnya adalah sama.

Di sini peneliti akan menformulasikan dari beberapa pendapat tersebut yang secara garis besar dapat disimpulkan sebagai berikut:
1. Pengadaan bahan pustaka

Kegiatan dalam pengadaan bahan pustaka yang terkait dengan kebutuhan otomasi perpustakaan adalah pencatatan permintaan, pemesanan dan pembayaran bahan pustaka, serta penerimaan dan laporan (reporting) proses pengadaan.

2. Pengolahan bahan pustaka

Kegiatan pengolahan yang terkait dengan kebutuhan otomasi perpustakaan meliputi kegiatan pemasukan data buku atau majalah, penelusuran status buku yang diproses, pemasukan cover buku, cetak label barcode (labeling barcode) dan nomor panggil (call number).

3. Penelusuran bahan pustaka

Penelusuran ini yang diperlukan mencakup berbagai alternatif pilihan yaitu penelusuran melalui pengarang, melalui judul, atau melalui subyek.

4. Manajemen Anggota (Administrasi)

Bidang otomasi yang diperlukan adalah pemasukan data anggota perpustakaan, dan pembuatan surat bebas perpustakaan.

5. Sirkulasi

Kegiatan pelayanan sirkulasi yang terkait dengan kebutuhan otomasi perpustakaan àdalah pencatatan peminjaman, pencatatan pengembalian, perpanjangan bahan pustaka, penghitungan denda dan pemesanan peminjaman buku.

6. Pelaporan (Reporting)

Pengelolaan laporan yang dibutuhkan adalah:

a. Menampilkan transaksi sirkulasi yang meliputi jumlah buku yang dipinjam, dan laporan denda

b. Menampilkan laporan koleksi yang meliputi jumlah koleksi keseluruhan, Jumlah koleksi 
berdasarkan subyek, Jumlah koleksi berdasarkan judul, jumlah koleksi berdasarkan pengarang, jumlah koleksi yang hilang serta laporan koleksi buku baru.

c. Menampilkan laporan anggota yang meliputi jumlah pengunjung, jumlah anggota dan jumlah anggota peminjam koleksi.

\section{Metode Penelitian}

Penelitian ini merupakan jenis penelitian deskriptif kualitatif.- Menurut Azwar (1999: 7) bahwa penelitian deskriptif bertujuanmenggambarkansecarasistematik dan akurat mengenai fakta dan karakteristik suatu populasi atau bidang tertentu. Penelitian ini berusaha menggambarkan situasi atau kejadian. Sedangkan makna penelitian kualitatif, penelitian kualitatif pada umumnya direncanakan untuk memberikan pengalaman senyatanya dan menerangkan makna sebagaimana yang tercipta di lapangan penelitian, melalui interaksi langsung antara peneliti dengan yang diteliti (Pendit, 2003).

\section{Subyek Dan Objek Penelitian}

Subyek penelitian adalah sumber utama data penelitian yang memiliki data mengenai variabel-variabel yang diteliti (Azwar, 1999). Subyek dari penelitian ini adalah evaluasi software aplikasi SIPUSTAKOM di perpustakaan STMIK AKAKOM dengan pendekatan kebutuhan otomasi. Sedangkan obyek penelitian merupakan sesuatu yang menjadi pokok pembicaraan atau tulisan. Objek dari penelitian ini adalah software aplikasi SIPUSTAKOM.

\section{Unit Analisis}

Unit analisis merupakan satuan tertentu yang diperhitungkan sebagai subyek penelitian (Arikunto, '1992). Adanya unit analisis ini sangat penting untuk memudahkan dalam pengumpulan data dan pengambilan simpulan. Unit analisis dalam penelitian ini adalah evaluasi software aplikasi SIPUSTAKOM. Sedangkan fokus dalam penelitian ini adalah kebutuhan otomasi perpustakaan STMIK AKAKOM yang berkaitan dengan modul utama otomasi perpustakaan. Dalam penelitian ini terdapat enam unit analisis yang terdiri dari unit analisis pengadaan bahan pustaka, pengolahan bahan pustaka, penelusuran bahan pustaka, manajemen anggota, 'sirkulasi, dan unit analisis yang berkaitan dengan pelaporan.

\section{Teknik Pengumpulan Data}

Teknik pengumpulan data yang digunakan dalam penelitian ini adalah observasi, wawancara dan dokumentasi.

\section{Metode Analisis Data}

Analisis data yang digunakan dalam penelitian ini menggunakan metode analisis deskriptif yang bertujuan untuk memberikan deskripsi mengenai subyek penelitian berdasarkan data variabel yang diperoleh dari subyek yang diteliti dan tidak untuk pengujian hipotesis.

\section{Pembahasan Hasil Penelitian}

Dalam analisis ini peneliti akan menguraikan indikator apa saja yang dapat dipenuhi dan tidak dapat dipenuhi oleh software SIPUSTAKOM sehingga dapat ditarik suatu kesimpulan. Setelah memperhatikan modul SIPUSTAKOM, melakukan wawancara dengan informan dan melalukan observasi dengan cara tes ujicoba terhadap software tersebut, maka peneliti akan menjabarkan hasil penelitian sebagai berikut: 


\section{Pengadaan bahan pustaka}

Pada unit analisis pengadaan bahan pustaka terdapat empat indikator yang terdiri dari pencatatan permintaan, pemesanan dan pembayaran, penerimaan pengadaan dan laporan pengadaan. Berdasarkan wawancara dengan informan bahwa menu untuk pengadaan belum disediakan oleh SIPUSTAKOM. Hal tersebut didukung dengan memperhatikan modul dan hasil pengetesan terhadap aplikasi memang belum menyediakan menu tersebut. Dengan demikian dapat diketahui bahwa SIPUSTAKOM - belum mampu memenuhi empat indikator yaitu pencatatan permintaan, pemesanan dan pembayaran, penerimaan pengadaan serta laporan pengadaan.

\section{Pengolahan bahan pustaka}

Unit analisis pengolahan bahan pustaka terdapat empat indikator yaitu:

\section{a. Input data koleksi}

Aplikasi SIPUSTAKOM memiliki submenu input data koleksi atau pemasukan data buku. Berdasarkan tes dengan cara. uji coba mengoperasikan software ditambahkan dengan wawancara dengan informan terhadàp fasilitas submenu "pemasukan data buku", dapat diketahui bahwa fasilitas tersebut dapat berfungsi dengan baik, dengan demikian indikator input data koleksi dapat dipenuhi. Berikut ini adalah gambar tampilan input data koleksi.

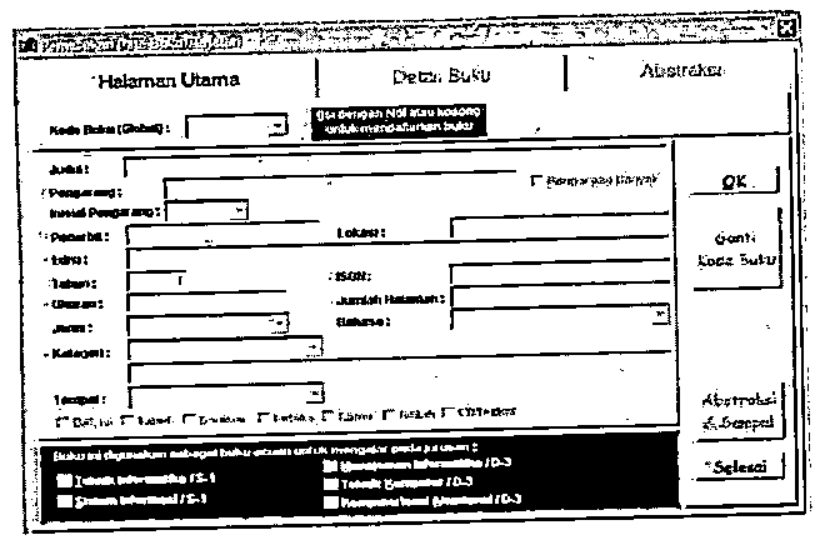

Gambar Submenu Input Data Koleksi

\section{b. Penelusuran status buku yang diproses}

Menu untuk penelusuran status buku yang diproses tidak disediakan oleh SIPUSTAKOM. Berdasarkan wawancara dengan informan tersebut dan ditambahkan dengan hasil pengetesan dan dapat diketahui bahwa SIPUSTAKOM tidak memiliki menu tersebut sehingga untuk indikator ini belum terpenuhi.

\section{c. Pemasukan cover buku}

SIPUSTAKOM sudah mempunyai fasilitas untuk memasukkan cover yang menunjukkan informasi judul ataupun pengarang buku meskipun fasilitas tersebut belum pernah digunakan. Tampilan form submenu input data adalah berikut ini.

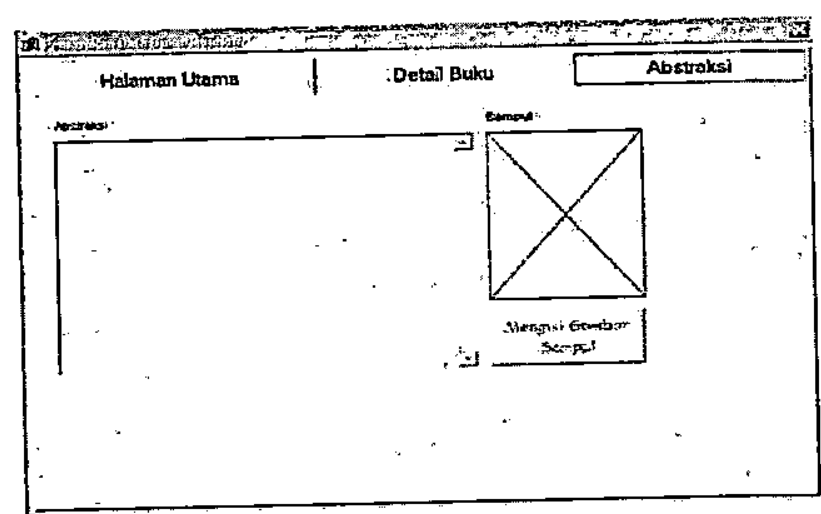

Gambar Submenu Pemasukan Cover Buku

Dengan memperhatikan modul, hasil tes dan wawancara dapat ditarik kesimpulan bahwa SIPUSTAKOM dapat memenuhi indikator pemasukan cover buku.

\section{d. Cetak label barcode (labeling barcode) dan nomor panggil (call number)}

Cara mencetak label barcode dan nómor panggil dilakukan dengan cara membuka menu "utilitas" kemudian pilih membuat label (dengan barcode). Setelah itu petugas memasukkan kode barcode buku yang akan dicetak dan langkah selanjutnya 
adalah tekan box "cetak". Berdasarkan hasil wawancara dan didukung oleh tes dapat disimpulkan bahwa SIPUSTAKOM memenuhi indikator cetak label barcode dan nomor panggil. Berikut ini adalah tampilan cetak.label dan nomor panggil.

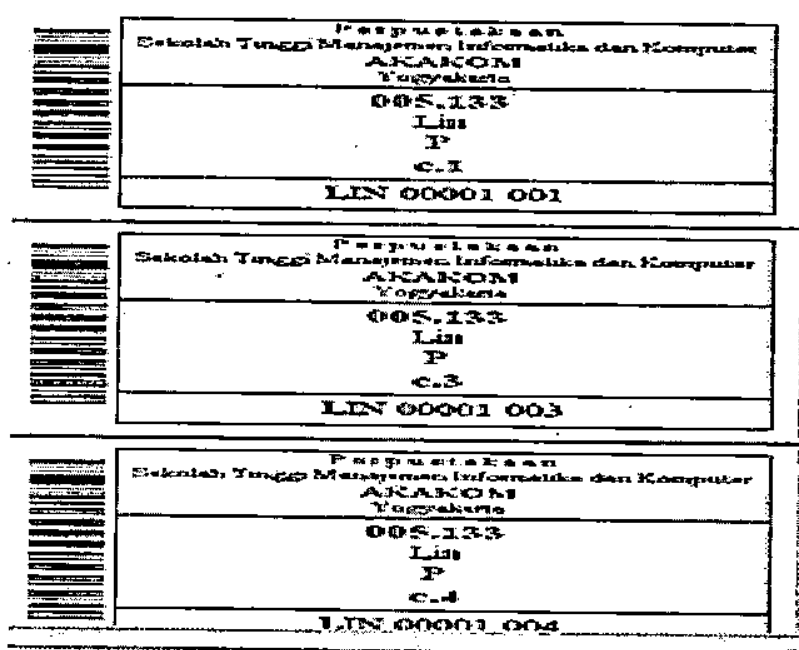

Gambar Label Siap Cetak

\section{Penelusuran bahan pustaka}

Pembahasan dari indikator penelusuran melalui pengarang, penelusuran melalui judul, dan penelusuran melalui subyek adalah sebagai berikut.

\section{a. Penelusuran berdasarkan pengarang}

Pencarian atau penelusuran bahan pustaka dapat dilakukan melalui pengarang. Hal tersebut dapat dilakukan dengan cara membuka menu "laporan/ informasi" kemudian pilih "mencari buku via judul/pengarang" dan pilih kolom pilihan pengarang. Dari hasil cek modul, wawancara dan pengetesan dapat diketahui bahwa SIPUSTAKOM dapat memenuhi indikator penelusuran berdasarkan pengarang.

\section{b. Penelusuran berdasarkan judul}

Fasilitas penelusuran bahan pustaka melalui judul juga dimiliki oleh SIPUSTAKOM. Cara yang dilakukan oleh user sama seperti dengan penelusuran melalui pengarang yaitu melaiui proses membuka menu "laporan/informasi” Berikut ini adalah tampilan fasilitas pencarian buku berdasarkan judul dan tampilan detail diskripși bibliografi. Dari hasil wawancara, cek modul dan dikuatkan dengan tes serta observasi lapangan dapat diketahui bahwa indikator penelusuran bahan pustaka melalui judul dapat dipenuhi oleh SIPUSTAKOM.
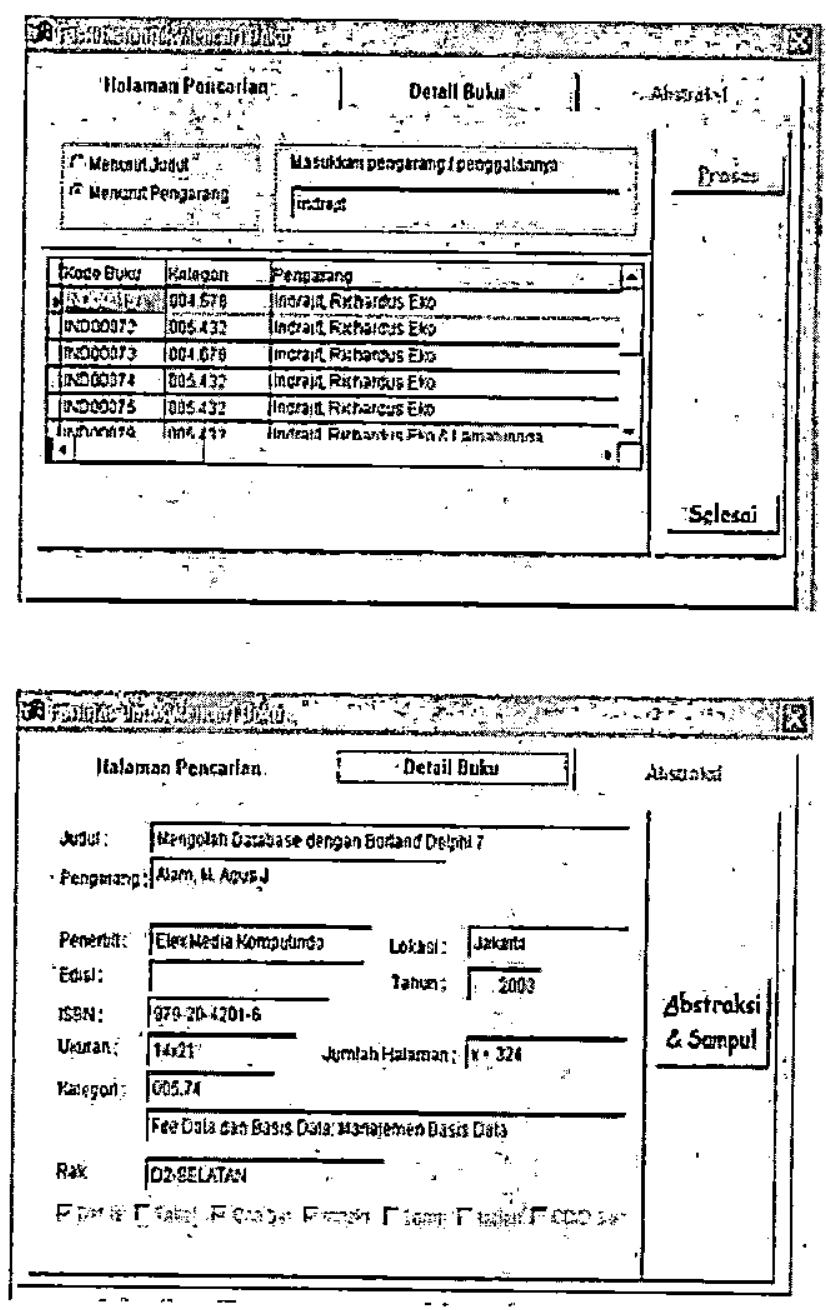

Gambar Hasil Pencarian Buku

\section{c. Penefiusuran berdasarkan subyek}

Dari hasil observasi, wawancara dan dikuatkan dengan tes dengan cara uji coba mengoperasikan software aplikasi SIPUSTAKOM bahwa aplikasi tersebut belum mampu memenuhi indikator penelusuran bahan pustaka berdasarkan subyek. 


\section{Manajemen anggota}

Bidang otomasi yang diperlukan dalam manajemen anggota adalah input data anggota perpustakaan, dan pembuatan surat bebas perpustakaan. Analisis dari indikator input data anggota perpustakaan, dan pembuatan surat bebas perpustakaan tersebut adalah sebagai berikut:

\section{a. Input data anggota perpustakaan}

Perpustakaan tidak bisa dan tidak mempunyai otoritas untuk menghapus atau memasukkan data anggota melalui SIPUSTAKOM karena fasilitas pemasukan data Dengan demikian software aplikasi ini belum bisa melakukan input data anggota perpustakaan secara mandiri sehingga untuk indikator input data anggota perpustakaan belum dapat terpenuhi oleh aplikasi SIPUSTAKOM.

\section{b. Pembuatan surat bebas perpustakaan}

SIPUSTAKOM sudah menyediakan fasilitas tersebut Pembuatan surat bebas perpustakaan dilakukan dengan cara klik menu "utilitas" kemudian pilih submenu "membuat surat bebas pinjam". Berikut ini adalah tampilan pembuatan surat bebas perpustakaan.

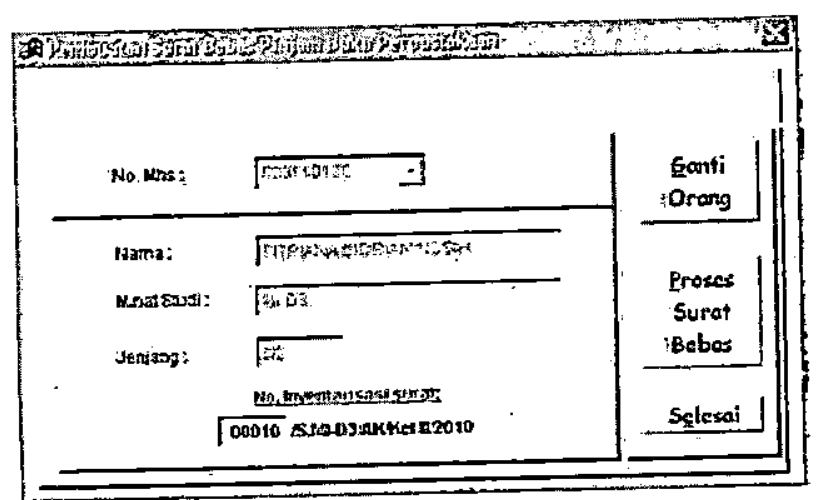

Gambar 12. Submenu Membuat Surat Bebas perpustakaan

Dari hasil informasi dari informan tersebut, dan didasarkan dari hasil tes diketahui bahwa indikator membuat surat bebas perpustakaan dapat terpenuhi.

\section{Sirkulasi}

Kegiatan sirkülasi yang dibutuhkan dalam otomasi perpustakaan adalah pencatatan peminjaman, pencatatan pengembalian, penghitungan denda dan pemesanan peminjaman buku. Komponenkomponen tersebut merupakan indikator dalam penelitian ini. Dari hasil cek modul, pengamatan serta pengetesan diketahui bahwa SIPUSTAKOM mempunyai fasilitas peminjaman, pengembalian, perpanjangan dan penghitungan denda sehingga ketiga indikator tersebut sudah terpenuhi. Sedangkan fasilitas pemesanan peminjaman buku, SIPUSTAKOM tidak memiliki fasilitas menu untuk pemesanan bahan pustaka sehingga indikator pemesanan peminjaman buku belum terpenuhi.

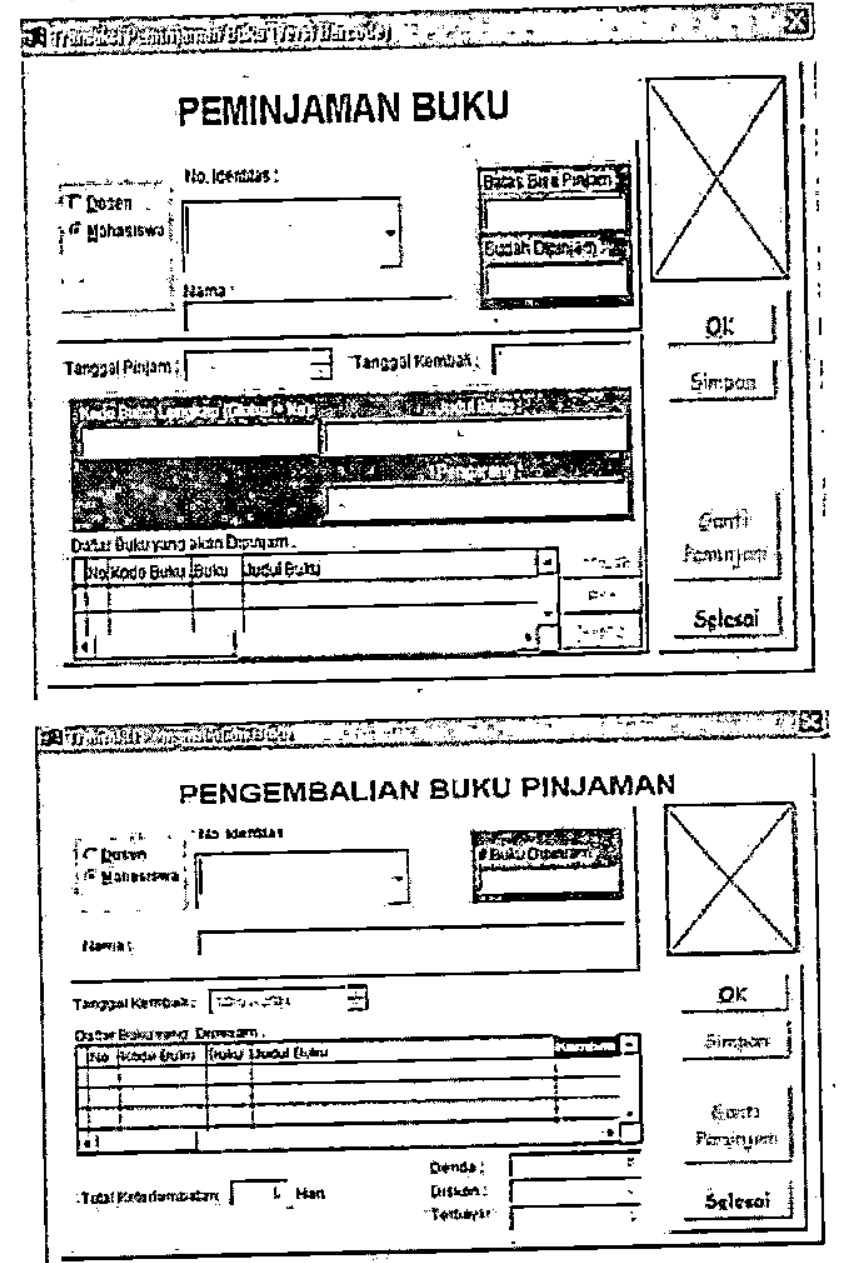




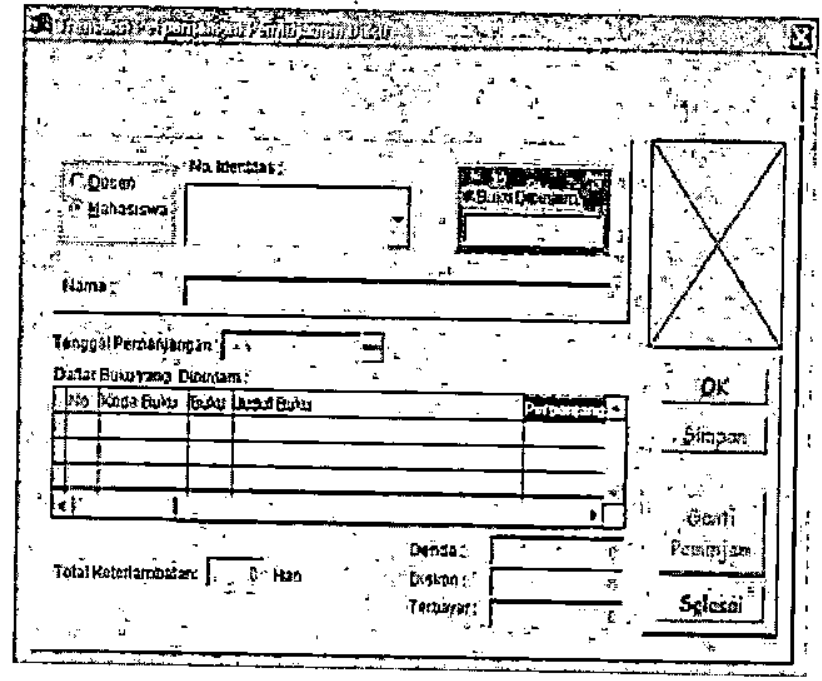

Gambar Submenu Transaksi Peminjaman, Pengembalian Dan PerpanjanganBuku

\section{Pelaporan}

Berikut ini adalah pembahasan dari masing-masing indikator dalam pelaporan:

\section{a. Laporan jumlah buku yang dipinjam}

Informasi jumlah buku yang dipinjam telah disediakan oleh SIPUSTAKOM. Untuk mengetahui informasi tersebut caranya dengan membuka menu "laporan/ informasi" kemudian pilih "informasi statistik peminjaman buku". Setelah itu petugas mengetikan tahun yang diinginkan dan langkah selanjutnya adalah klik "proses". Dari hasil wawancara dan dibuktikan dengan pengetesan dengan cara menguji coba software aplikasi SIPUSTAKOM dapat dilihat bahwa SIPUSTAKOM telah menyediakan fasilitas tersebut sehingga indikator ini mampu terpenuhi. Berikut ini adalah tampilan informasi atau laporan jumlah buku yang dipinjam.

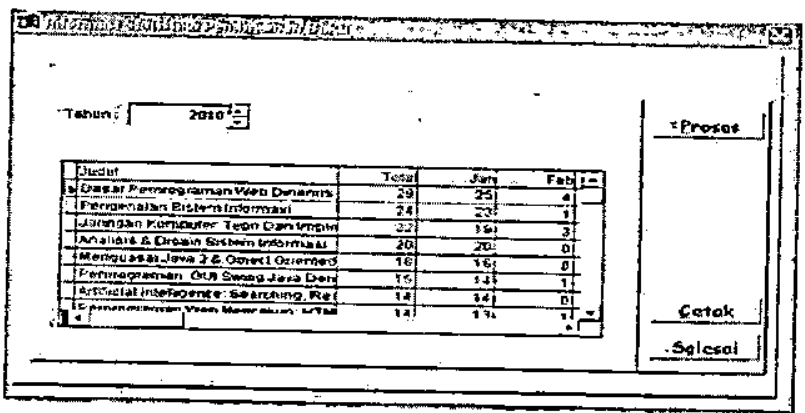

Gambar Tampilan Informasi Jumlah Buku yang Dipinjam

\section{b. Laporan denda}

Software SIPUSTAKOM telah memberikan fasilitas informasi denda.untuk periode tertentu tergantung permintaan operator (petugas). Untuk bisa melihat laporan denda adalah dengan membuka menu "laporan/informasi" kemudian .pilih submenu "denda". Setelah itu kemudian mengisikan periode berdasarkan tanggal, bulan, tahun yang diinginkan sampai dengan periode yang diinginkan juga diketikkan. Kemudian setelah itu klik "proses". Dari hasil cek dokumen, wawancara dan hasil pengetesan diketahui bahwa SIPUSTAKOM mampu memberikan informasi laporan denda dengan baik sehingga software tersebut dapat memenuhi indikator laporan atau informasi denda. Berikut ini gambar tampilan informasi pembayaran denda.

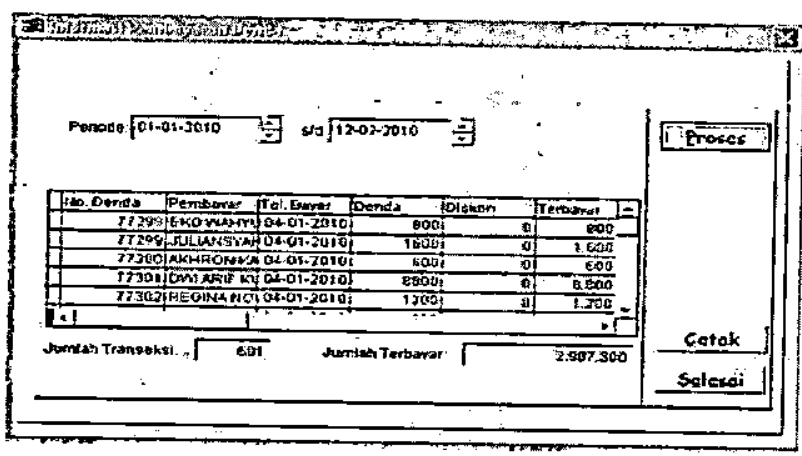

Gambar Tampilan Informasi Pembayaran Denda

\section{c. Laporan jumlah koleksi keseluruhan}

Di dalam SIPUSTAKOM informasi mengenai jumlah koleksi dapat dilihat dengan membuka fasilitas menu "laporan/ informasi" kemudian pilih submenu "penambahan buku", kemudian mengetikan jumlah buku dalam periode tertentu sesuai dengan kebutuhan. Dengan demikian, berdasarkan hasil wawancara dengan informan dan dibuktikan dengan pengetesan dengan cara menguji coba software aplikasi diketahui bahwa SIPUSTAKOM bisa memenuhi indikator laporan jumlah koleksi keseluruhan. 


\section{d. Laporan koleksi berdasarkan pengarang}

Apabila pengguna perpustakaan atau pustakawan ingin mengetahui informasi mengenai jumlah koleksi berdasarkan nama pengarang, mereka merasa kesulitan karena SIPUSTAKOM tidak menyediakan menu atau submenu mengenai laporan jumlah koleksi berdasarkan pengarang. Berdasarkan hasil wawancara, uji coba serta cek dokumen SIPUSTAKOM dapat dikatakan belum mampu memenuhi kebutuhan otomasi dalam hal penyediaan fasilitas untuk mendapatkan informasi jumlah koleksi berdasarkan nama pengarang sehingga indikator laporan atau informasi koleksi berdasarkan pengarang tersebut belum dapat dipenuhi oleh aplikasi SIPUSTAKOM.

\section{e. Laporan koleksi berdasarkan judul}

Informasi mengenai jumlah koleksi berdasarkan judul bahan pustaka dapat dilihat dengan membuka menu "laporan/ informasi" kemudian pilih submenu "inventarisasi" kemudian klik kotak box pilihan "menurut judul". Uji aplikasi dan wawancara yang peneliti lakukan dapat diketahui bahwa SIPUSTAKOM mampu dan dapat memenuhi indikator laporan koleksi berdasarkan judul. Berikut ini adalah tampilan laporan koleksi berdasarkan judul.

\section{f. Laporan koleksi berdasarkan subyek}

Fasilitas untuk mengetahui informasi jumlah koleksi berdasarkan subyek juga sudah disediakan oleh aplikasi SIPUSTAKOM. Cara yang dilakukan untuk mendapatkan informasi tersebut sama dengan mencari informasi jumlah koleksi berdasarkan judul tetapi yang dipilih adalah klik kotak box pilihan "menurut kategori" (subyek suatu bahan pustaka). Berdasarkan wawancara dengan informan dan dibuktikan dengan uji coba software diketahui bahwa SIPUSTAKOM mampu dan dapat memenuhi indikator laporan koleksi berdasar subyek. Tampilan laporan koleksi berdasarkan subyek adalah sebagai berikut.
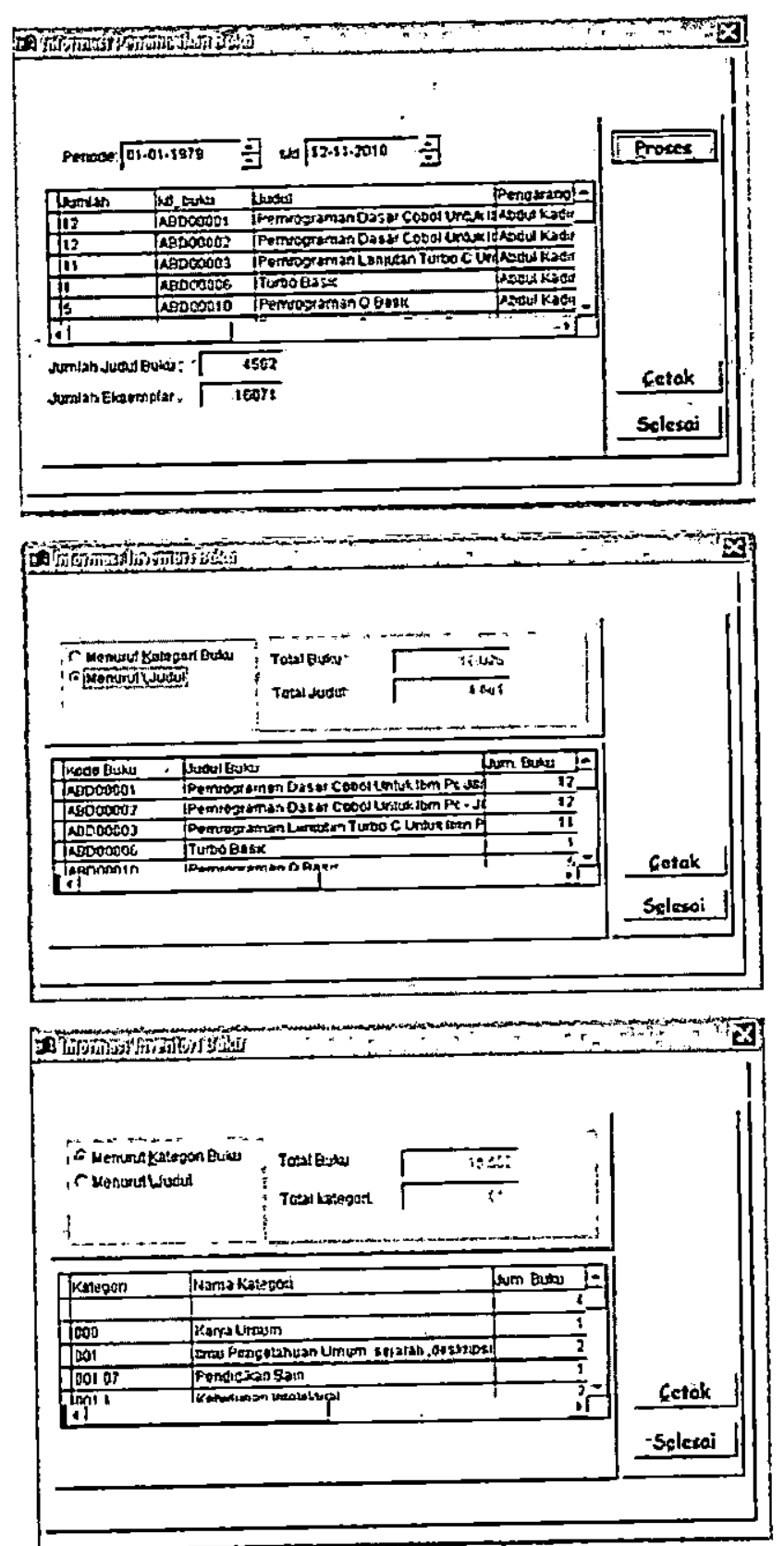

Gambar Laporan Keseluruhan, Koleksi Berdasarkan judul dan Subyek

\section{g. Laporan buku yang hilang}

Pengecekan buku-buku yang tidak ada di jajaran rak tidak mudah dilakukan petugas karena masih bersifat manual. 
Informasi mengenai buku yang hilang belum bisa ditampilkan oleh SIPUSTAKOM. Dari hasil wawancara dengan informan dan uji coba mengoperasikan software dapat diketahui bahwa SIPUSTÁKOMM belum mempunyai fasilitas untuk mencari infomasi mengenai buku yang hilang sehingga untuk indikator laporan buku yang hilang belum dapat terpenuhi.

\section{h. Laporan koleksi buku baru}

Laporanbukubaruiniadalahinformasi koleksi yang disajikan dalam satu bulan terakhir. Menurut informasi dari informan SIPUSTAKOM dapat menampilkan koleksi buku baru yang dimiliki perpustakaan. $\mathrm{Hal}$ tersebut didukung dengan pengetesan aplikasi SIPUSTAKOM yang telah dilakukan oleh peneliti bahwa SIPUSTAKOM memang benar-benar bisa menyajikan laporan tersebut. Dengan demikian dapat diketahui bahwa SIPUSTAKOM mampu memenuhi indikator laporan atau informasi koleksi buku baru. Tampilan koieksi buku baru dapat dilihat dibawah ini.

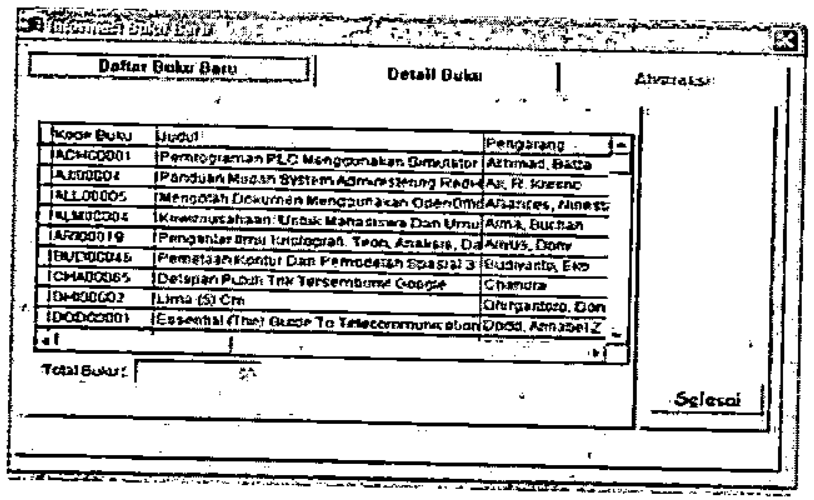

Gambar. Tampilan Koleksi Buku Baru

\section{i. Laporan jumlah pengunjung}

Statistik jumiah pengunjung sangat bermanfaat untuk mengetahui perkembangan seberapa banyak jumlah pengunjung dan tingkat kunjungan perpustakaan. Terkait dengan kebutuhan otomasi, software yang baik seharusnya memiliki fasilitas yang dapat memberikan informasi jumlah pengunjung. Berdasarkan modul, wawancara dan pengetesan yang telah peneliti lakukan, SIPUSTAKOM belum bisa menampilkan laporan jumlah pengunjung. Dengan demikian SIPUSTAKOM belum mampu memenuhi indikator informasi atau laporan jumlah pengunjung.

\section{j. Laporan jumlah anggota}

Software aplikasi SIPUSTAKOM hanya mampu menampilkan laporan mahasiswa yang aktif. Laporan tersebut tidak mencerminkan jumlah anggota secara keseluruhan Jadi berdasarkan hasil wawancara dan uji coba, software SIPUSTAKOM tidak memiliki menu untuk menampilkan informasi jumlah anggota secara keseluruhan. Dengan demikian pembuatan laporan secara mandiri mengenai jumlah anggota perpustakaan belum mampu disajikan oleh SIPUSTAKOM sehingga untuk indikator pembuatan laporan jumlah anggota belum dapat dipenuhi oleh software aplikasi SIPUSTAKOM.

\section{k. Laporan anggotà peminjam koleksi}

Untuk dapat mengetahui data jumlah anggota peminjam bahan pustaka dapat dilihat pada menu "laporan/informasi" kemudian pilih submenu "peminjaman" yang berisi informasi angota peminjam buku. Dari submenu ini user juga bisa melakukan pencarian terhadap buku yang sedang dipinjam oleh pemustaka yaitu dengan cara klik "cari buku dipinjam via kode detail" yang dilakukan dengan cara mengetikan kode barcode buku secara detail misalnya "AGU0001 001". Berdasarkan hasil wawancara-tersebut dan dikuatkan pengetesan SIPUSTAKOM memiliki menu untuk menampilkan informasi jumlah anggota yang meminjam koleksi secara keseluruhan sehingga dapat memenuhi indikator tersebut. 
Evaluasi Kualitas Software "Sipustakom"... (Sri Wahyuni)

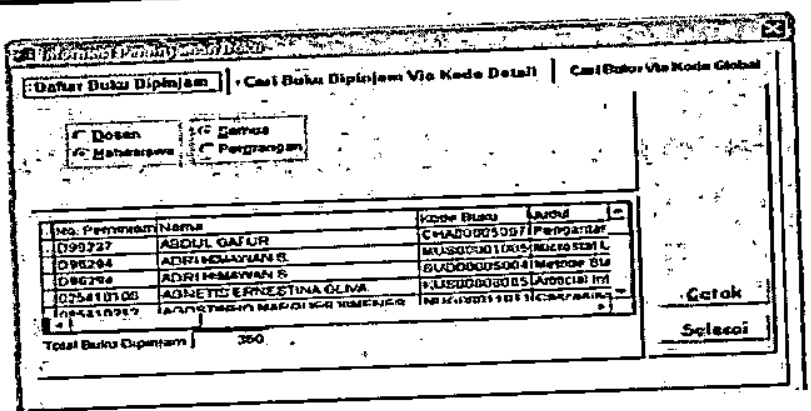

Setelah dilakukan evaluasi atau penilaian terhadap semua unit analisis penelitian yang terdiri dari dua puluh sembilan fokus penelitian atau disebut juga indikator penelitian, maka hasilnya dapat dilihat tabel jumlah item pemenuhan kebutuhan otomasi.

Gambar. Tampilan Anggota Peminjam Kolẹksi

Tabel Hasil Item Pemenuhan Kebutuhan Otomasi

\begin{tabular}{|c|c|c|c|c|}
\hline No & Indikator & Jmlah item & $\begin{array}{c}\text { Item } \\
\text { terpenuhi }\end{array}$ & $\begin{array}{l}\text { Item tidak } \\
\text { terpenuhi }\end{array}$ \\
\hline 1 & Pencatatan permintaan & 1 & 0 & 1 \\
\hline 2 & Pemesanan dan pembayaran & 1 & 0 & 1 \\
\hline 3 & Penerimaaan pengadaan & 1 & 0 & 1 \\
\hline 4 & \begin{tabular}{|l} 
Laporan pengadaan \\
\end{tabular} & 1 & 0 & 1 \\
\hline 5 & $\begin{array}{l}\text { Input data koleksi } \\
\end{array}$ & 1 & 1 & 0 \\
\hline 6 & Penelusuran status buku yang diproses & 1 & 0 & 1 \\
\hline 7 & $\begin{array}{l}\text { Pemasukan cover buku } \\
\end{array}$ & 1 & 1 & 0 \\
\hline 8 & Cetak label barcode dan nomor panggil & 1 & 1 & 0 \\
\hline 9 & Penelusuran berdasarkan pengarang & 1 & 1 & 0 \\
\hline 10 & \begin{tabular}{|l|} 
Penelusuran berdasarkan judul \\
\end{tabular} & 1 & 1 & 0 \\
\hline 11 & Penelusuran berdasarkan subyek & 1 & 0 & 1 \\
\hline 12 & \begin{tabular}{|l|} 
Input data anggota \\
\end{tabular} & 1 & 0 & 1 \\
\hline 13 & Pemput batan surat bebas perpustakaan. & 1 & 1 & 0 \\
\hline 14 & Peminjaman & 1 & 1 & 0 \\
\hline 15 & \begin{tabular}{|l} 
Peminjuandin \\
Pengembalian \\
\end{tabular} & 1 & 1 & 0 \\
\hline 16 & \begin{tabular}{|l} 
Pengembiallan \\
Perpanjangan \\
\end{tabular} & 1 & 1 & 0 \\
\hline 17 & \begin{tabular}{|l} 
Perpanjangan \\
Penghitungan denda \\
\end{tabular} & 1 & 1 & 0 \\
\hline 18 & Pemesanan peminjaman buku & 1 & 0 & 1 \\
\hline 19 & \begin{tabular}{|l|} 
Menampilkan jumlah buku yang dipinjam \\
\end{tabular} & 1 & 1 & 0 \\
\hline 20 & Menampilkan laporan denda & 1 & 1 & 0 \\
\hline 21 & Menampilkan jumlah koleksi keseluruhan & 1 & 1 & 0 \\
\hline 22 & Menampilkan koleksi berdasarkan pengarang & \begin{tabular}{|l|} 
\\
\end{tabular} & 0 & 1 \\
\hline 23 & $\begin{array}{l}\text { Menampikan koleksi berdasarkan judul } \\
\text { Menampilkan koleksi bisk }\end{array}$ & 1 & 1 & 0 \\
\hline 24 & $\begin{array}{l}\text { Menamplikan koleksi berdasarkan subyek } \\
\text { Menampikan kolek }\end{array}$ & 1 & 1 & 0 \\
\hline 25 & \begin{tabular}{|l} 
Menampilkan buku yang hilang \\
\end{tabular} & 1 & 0 & 1 \\
\hline 26 & Menampilkan koleksi buku baru & 1 & 1 & 0 \\
\hline 27 & \begin{tabular}{|l} 
Menampikan Konerilkan laporan jumlah pengunjung \\
Menampin
\end{tabular} & 1 & 0 & 1 \\
\hline 28 & Menampilkan laporan jumlah anggota & 1 & 0 & 1 \\
\hline 29 & Menampilkan anggota peminjam koleksi & 1 & 1 & 0 \\
\hline & \begin{tabular}{|l|l|} 
Menamplikan anggota pering \\
Jumlah Total Item
\end{tabular} & 29 & 17 & 12 \\
\hline
\end{tabular}


Kesimpulan

Dari analisis yang telah dilakukan, maka peneliti menyimpulkan bahwa software apikasi SIPUSTAKOM sudah mampu memenuhi lebih dari separuh kebutuhan otomasi di perpustakaan STMIK AKAKOM. Dari dua puluh sembilan item kebutuhan otomasi, software aplikasi SIPUSTAKOM mampu memenuhi tujuh belas item dalam pemenuhan kebutuhan otomasi:perpustakaan STMIKAKAKOM Yogyakarta dan masih ada dua belas item yang belum mampu terpenuhi oleh software aplikasi SIPUSTAKOM.

\section{Saran}

1. Sebaiknya software aplikasi SIPUSTAKOM perlu diuji coba oleh perpustakaan lain dan dilepas untuk perpustakaan lain sehingga dapat diketahui oleh berbagai jenis perpustakaan serta dikembangkan lebih lanjut serta dapat menjadi sistem otomasi pada umumnya.

2. Pelu adanya penambahan fasilitas yang lebih lengkap dan penelitian lanjutan mengenai software aplikasi SIPUSTAKOM yang mengevaluasi user interfacenya sehingga dapat diketahui "kualitas antarmuka" software tersebut apakah sudah memenuhi kriteria "ramah dengan pengguna".

\section{Daftar Pustaka}

Anonim. 1996. Kamus Komputer: Standar Lengkap Untuk Bisnis, Sekolah, Perpustakaan Dan Rumah. Jakarta: Gramedia Pustaka Utama

Arikunto, Suharsimi. 1998. Prosedur Penelitian: Suatu Pendekatan Praktek. Jakarta: Rineka Cipta.

Azwar, Saifuddin. 1999. Metode Penelitian. Cet.ll. Yogyakarta: Pustaka Pelajar.

Direktorat Jendral Pendidikan. Tinggi. 2004. Perpustakaan Perguruan
Tinggi: Buku Pedoman.Jakarta: Departemen Pendidikan Nasional.

Hakim, Heri Abi Burachman. 2008. "Evaluasi Kualitas Openbiblio Sebagai Perangkat 'Lunak Otomasi Perpustakaan Berbasis Open "Source" (skripsi).' Jurusan IImu Perpustakaan Fakultas Adab, UIN Sunan Kalijaga Yogyakarta.

Kadir, Abdul dan Terra @h Triwahyuni. 2005. Pengenalan Teknologi Informasi. Yogyakarta: Andi.

Pendit, Putu Laxman. 2003. Penelitian IImu Perpustakaan Dan Informasi: Suatu Pengantar Diskusi EpistimologiDan Metodologi. Cetakan ke-1. Jakarta: JIP-FSUI.

Setiawan, Agus. 2005. Pengantar Sistem Komputer. Edisi Revisi. Bandung: Informatika

Supriyanto, Aji. 2005. Pengantar Teknologi Informasi. Jakarta: Salemba Infotek.

Supriyanto, Wahyu dan Ahmad Muhsin. 2008. Teknologi Informasi Perpustakaan. Yogyakarta: Kanisius. 